\title{
Leadership and Power Game in a Multi-Polarizing World: The Competition between the US and China
}

\author{
Alexandra Jingsi Ni \\ The CEAS, University of Turku, Turku, Finland \\ Email: alexa.jingsi.ni@gmail.com
}

How to cite this paper: Ni, A. J. (2020). Leadership and Power Game in a Multi-Polarizing World: The Competition between the US and China. Open Journal of Political Science, 10, 253-277.

https://doi.org/10.4236/ojps.2020.102017

Received: January 24, 2020

Accepted: March 23, 2020

Published: March 26, 2020

Copyright ( $\odot 2020$ by author(s) and Scientific Research Publishing Inc. This work is licensed under the Creative Commons Attribution International License (CC BY 4.0).

http://creativecommons.org/licenses/by/4.0/

\section{(c) (i) Open Access}

\begin{abstract}
The vigorous rise of China has deeply impressed the world. Many believers of the power transition theory suspect that an increasingly powerful China would ultimately threaten the global domination of the US, i.e. the China Threat thesis (中国威胁论), and replace the US to become the next hegemon. However, the reality is far more complex and complicated than this provocative prophecy, which necessitates a piece of holistic research to shed light on the escalating competition between the US and China. This article is based on solid secondary data and information that has been collected from publically available academic literature and formal political discourse. This article is an evidence-based, critical interpretation of the intensifying power game between the US and China against the concept of leadership. The controversial Trump Administration in the US and the revisionist Xi Administration in China represent distinctively different leadership styles and these two administrations have hugely divergent visions and understandings of the global political economy. In this article, I conclude that: 1) the unilateral and isolationist behaviors of the US under the leadership of Donald Trump is jeopardizing its own hegemonic leadership and undermining the collective strength of the global West; 2) China remains in a defensive position and is reluctant to burden itself with resource-consuming external power game and 3) the almost incompatible strategic thinking and calculations of the Trump Administration and Xi Administration have largely contributed to the intensifying US-China competition despite the strong presence of internal demand for attention and resources.
\end{abstract}

\section{Keywords}

Leadership, The Rise of China, Global Political Economy, US-China Power Politics, Multipolarization 


\section{Introduction}

Leadership is an important concept existed in many disciplines, such as in political science and business studies (Rost, 2008). Leadership is often theorized as a set of processes of influences leading to varied outcomes through "initiating collective agency” (Molchanov, Knight, \& Masciulli, 2016: p. xv). Leadership bears inherent complexity. The concept per se is multi-faceted and it has varied definitions in the literature (Dyer, 2019). In practice, leadership is a prevalent form of power delegation within an organizational structure (Oforchukwu, 2011). Essentially, a legitimate leadership is voluntarily authorized by the principle based on mutual trust and bilateral agreement (ibid.). The competence of the leadership could significantly affect the realization of the collective objectives and goals within an organized existence, which is the most relevant criterion to evaluate the quality of the leadership (Karadağ, 2015). However, disqualified leadership and dysfunctional leadership have been widely observed in reality and thoroughly researched by a large number of theorists. In general, they tend to attribute various organizational deficiencies or even failures to the problematic leadership in place (Edmondson, 2013).

Since leadership could manifest in different scales through a great variety of organizational forms and representations, such as being a department director of a large corporation or being the leader of an oppositional political party, for example. In the main section of the article, I shall elaborate on the intensifying power politics between the US and China against the concept of leadership to argue the following three points: 1) the Trump Administration and the Xi administration represent a force of change. These two administrations are trying very hard to foster decisive changes in their native country in order to satisfy the domestic imperatives emerged from the local society; 2) the national interests of the US and that of China are irreconcilable and it is the fundamental cause of the escalating US-China competition or even confrontation; 3) how China has been steadily expanding international influences and building up foreign relationships beyond its national borders through reinvention and application of its own political heritage and filling the potential leadership vacuums left by the de facto US strategic retreat.

An up-to-date comparative analysis of the US and Chinese leaderships is necessary and beneficial, both theoretically and practically. This article follows a classic structure of introduction, main body and conclusion. Main arguments would be presented in the main body of the article, which is divided into five interrelated sub-sections. This article intends to critically examine the current US leadership and Chinese leadership from selective angles at mesoscopic and macroscopic levels. Scope is deliberately prioritized over depth. The entire research is cautiously framed in the context of the on-going US-China power game. Neo-realism, constructivism and neo-institutionalism are the three most well-established theoretical schools in the discipline of political science. I deliberately choose to pursue an approach of theoretical hybridization in this article in 
an attempt to synergize their collective explanatory power and minimize their respective weaknesses, thus enhancing the overall quality of my arguments and conclusions.

\section{Trump VS Xi: change, retreat and preemption}

The central arena of global power politics in the $21^{\text {st }}$ Century undoubtedly belongs to the US and China. The so-called "global leadership" is believed to be the ultimate prize for the eventual winner of this new round of fierce competition. Many political observers and strategists agree that the national power of the US has been relatively declining over the recent decades (Acharya, 2018). However, others still hold a healthy dose of cautious optimism regarding the hegemon's ability to reinvigorate itself and prolong the existence of the hegemonic system in the limited future (Nye, 2016).

The vigorous rise of China has caused spreading unease and alert in the Western camp due to the fact that China seems to possess all the crucial potentialities to become a true global superpower in the foreseeable future. Unlike other highly suspected candidates, such as Japan and India, China has vast national territory; an enormous amount of human resources and satisfactory natural endowments (although, critical energy constraints do exist for China); a colossal economy with improving productivity and sophistication and the undisputable military might with the on-going modernization of the People's Liberation Army (the PLA: 中国人民解放军) all at the same time. In plain words, China is the real deal on the table.

Both the US and China have the apparent strategic intention to retain or gain power simply because the world still operates according to the logic of realism. Hard power is the most direct and effective instrument to secure and advance their expansive national interests in an increasingly globalized world. The intensifying power game between the US and China at the current moment is triggered by the "tariff war" instigated by the Trump Administration in mid-2018. The on-going trade friction between the US and China has caused significant damage to the domestic economy on both sides and even beyond. Nevertheless, in comparison, China has suffered more severely than the US because the Chinese economy still relies heavily on export and its ability to hedge the negative impact from the US is not sufficiently strong.

First and foremost, leadership should not be misunderstood as merely a softened and polite alternative for authority or domination, not even for hard-core realists, simply because this term does imply voluntary cooperation and mutual trust among the multitude of political-economic agents and entities (Sterling-Folker, 2002; Medeiros, 2009; Solomon \& Quinney, 2010). As mentioned earlier, leadership could manifest in a full spectrum of scales and could take any organizational forms possible (Busch, 2014). The de facto absence of a centralized authority at international level, in reality, leads many to speculate that whether or not the so-called "global leadership" assigned to the US has ever really existed.

As constructivists constantly argue, international politics is still characterized 
by a considerable level of disorder despite the presence of well-established international organizations and institutions, such as the United Nations (the UN: 联 合国), often due to the divergent or even irreconcilable national interests among competing sovereign entities (Green, 2015). In other words, the existing international organizations and institutions do not function as effectively as the initial collective agenda has cautiously planned and they are likely to be skillfully circumvented or even outright ignored by powerful nation-states in real-life situations. Therefore, some theorists suggest that a morally responsible and organizationally effective "global leadership" could potentially mitigate the undesirable disorder at inter-state level and provide a certain level of stability and regulation to the volatile global system (Sobel, 2013). Arguments along this line give credits to the role the US plays as the so-called "benign hegemon", although many others are not easily convinced by this claim (Bergeijk, Okano-Heijmans, \& Melissen, 2011).

They argue that the history clearly shows that the hegemon tends to resort to hard power whenever circumstances arise, such as the unauthorized and much opposed US military interventions in foreign soils (Sterling-Folker, 2002; Leverett \& Indyk, 2005; Podliska, 2010). Realists insist that the arbitrary and abusive behaviors committed by powerful states reveal a de facto "political jungle" (丛林 政治) in existence, which reinforces the time-honored realist assumption that states have to compete with one another in order to survive in the harsh reality of a self-help global system (Baldwin, 2008). In this scenario, all states suffer from perpetual insecurity and distrust (ibid.). This anarchic inclination has very persistent effects on the behaviors of all states and, unfortunately, often in the form of self-fulfilling prophecy.

At this point, the Trump Administration is pursuing an unprecedentedly unilateral avenue to achieve the two primary strategic goals President Trump consistently claims, namely: 1) putting America's national security and interests above literally anything else and 2) securing America's prominent status in the international community from whatever challenges that might be. In order to achieve these two goals, the Trump Administration has deployed dramatic measures to compensate the disproportionate institutional costs the US bears to sustain the deteriorating hegemonic system with economic or even directly financial gains from its allies and alignments and to aggressively contain China through trade war, economic disentanglement and technology embargo etc. President Trump has also demonstrated strong determination to reconfigure any undesirable institutional arrangements in place to ensure that the US remains to be the largest beneficiary of the evolving global order, if it does exist in some way, somehow.

Instead of focusing on externally-driven issues with huge expenditures, pressing domestic imperatives have gained much more attention and priority in recent years along with the resurgence of populism in the Western world. From a (quasi-)structural perspective, the de-organizational (去组织化) and/or re-organizational (重组织化) tendency in major Western societies is evident. 
The controversial Brexit (Coleman, 2017) and the resurgence of Mercantilism and various forms of trade protectionism in the US (Martin, 2018) are among the most convincing and up-to-date examples of the increasingly inward-looking mentality in major Western powers and the strong nationalistic sentiment have emerged from within the local society (Schmidt, Shelley, \& Bardes, 2018). If David Cameron was opportunist and miscalculated about the willingness of a sizeable proportion of the British people to walk away from the organizational umbrella of the EU, then the rise of Donald Trump at the other side of the Atlantic Ocean signals dramatic changes of policies, strategies and, more broadly and profoundly, institutions.

Donald Trump represents a very disruptive or even destructive force to the existing political understructure in the US (Mercer, 2016) and beyond. Trump has made numerous inflammatory remarks throughout his amateur political career, such as he believes the North Atlantic Treaty Organization (the NATO) is obsolete and the persistent trade deficits the US has with its major trading partners seriously hurt the national interests of the US. The recent withdrawal from the Intermediate-Range Nuclear Force Treaty (the INF Treaty: 中导条约) by President Trump has seriously shaken the foundation of the paradoxical nuclear peace during and after the end of the agonizing Cold War. Facing fierce criticisms both at home and abroad, Trump has lightly explained away his arbitrary decision by blaming the treaty itself being unfair to the US, namely too much unilateral obligations and too little benefits. A highly suspected strategic retreat of the US has become increasingly evident under the leadership of Donald Trump.

President Trump is a very unpredictable and impulsive political leader, even though many believe that he is no way to be qualified as a political leader, especially in conventional senses (Torres \& Sable, 2018). He seems to be very proud to be a so-called "game changer" (改变游戏规则者) in relation to the political establishment in Washington and even beyond (Ighodaro, 2017). Many attribute the rise of Donald Trump as a one-of-a-kind political phenomenon to the growing anti-establishment mentality in the American society (Fitzduff, 2017; Rackaway, 2017). Apart from the resurgence of populism, it's worth pointing out that the alienation of the elites from the masses and the exacerbating inequalities of various kinds are the fundamental causes of the unsettling political disturbances that we could readily observe in major Western societies (Bonn, 2010; Saunders, 2013; Doob, 2017). It's fairly clear that the elites have somehow betrayed the goodwill of the general public as well as their much valued interests over the years and, as a political revenge of some short, the general public refuses to support and cooperate with the elites any longer. They demand for change, almost immediate change, ranging from policy re-orientation to structural reform.

Nevertheless, change doesn't automatically guarantee success or, at least, improvement. There is technically no causal relationship between the two. Those so-to-speak changes initiated by President Trump are drastic and swift with willful determination. However, many have seriously expressed their strategic 
concerns about the significant detriments these dramatic changes could cause to the much cherished democracy in the United States as well as bankrupting the credibility of the already crumbling US global leadership (Monagan, 2016; Williams \& Prince, 2018). In short, the Trump Administration intends to literally dismantle any undesirable power structures in place and carve a very controversial way out of the structural constraints imposed by the existing institutional establishment at all levels. This is a warning sign of artificial acceleration of institutional decay and potential increase of political entropy, especially at inter-state level.

The Trump Administration is redefining the roles and functions the US performs with outrageous self-interest and ruthless aggression. Despite being aware of the potential strategic retreat of the US, China doesn't seem to be eager to claim the global leadership for itself neither. Even though being constantly subject to the harsh criticisms from the West due to its Communist political label, China carefully positions itself as an alternative model of governance and development with allegedly no intention whatsoever to dominate Asia or even the world. The Chinese political authority consistently emphasizes on the indispensable "Chinese characteristics (中国特色)" throughout its formal political discourse over the years (Qian, 2018). This distinctive usage of political language is nothing unintentional or odd. It is indeed a very clear and serious message from the Chinese political leadership to both domestic and international audiences that China would not follow the path of the Western powers, i.e. becoming a capitalist liberal democracy, and the country remains constantly vigilant and highly resistant towards purposeful Western assimilation (Nau \& Ollapally, 2013) or even the vicious "peaceful evolution" in all the possible forms and representations (Garver, 2018).

Many political observers based in the global West have shown little confidence in the sustainability of the Communist political regime in China. However, to their amazement, the Chinese Communist Party (the CCP: 中国共产党) has successfully managed to secure and consolidate its monopolistic political status in China in the past seven decades. Until the year of 2019, the CCP has officially broken the record set by the former Soviet Union (前苏联) with an organizational life span of exactly 69 years. The miraculous economic development and modernization throughout China have somehow justified the political competence and legitimacy of the CCP and, thus, have convinced many of its supporters both at home and abroad (Dickson, 2016). However, it is widely known that the CCP is plagued by rampant administrative corruption (Lagunes \& Rose-Ackerman, 2015) and other forms of inappropriate or even legally controversial political practices (Karatnycky \& Piano, 2018) since China is still ruled by almost unchallenged administrative power rather than robust rule of law, even the Chinese political leadership itself recognizes it.

The Xi Administration is clearly aware of the potential political crises facing the CCP if the party does not reform itself to meet the increasingly strong domestic imperatives from the Chinese general public, such as the pressing de- 
mand for clean governance, political transparency and genuine empowerment of the private sector (Zheng \& Huang, 2018). In response to the intense repulsion and resentment towards corruption in the Chinese society, the Xi-centered political leadership has invested an enormous amount of efforts to educate the Chinese bureaucrats from top-down and has deployed extremely tough measures to discipline and even punish the daring offenders in its own political system (Jiang, 2017a). Interestingly, this coincides with the urgent demand for political change in the US, even though, technically, these two political systems are fundamentally incompatible and they operate under very different mechanisms.

For the Xi Administration, just like its predecessors, its undisputable top strategic priority is to stay in power as long as possible. Whatever reforms are or might be taking place during the Xi Era would not touch on the political monopoly of the CCP in China. Nevertheless, the potential reforms could in fact improve the image and perception of the ruling party and serve as strategic instruments to preserve the political status quo indefinitely. Despite being consistently portrayed as benign and progressive by the mainstream Chinese media outlets, one should bear in mind that the CCP would literally go any length to secure its top priority at all costs, which is a survival instinct shared by all political parties around the world.

The Xi Administration has a very distinctive leadership signature. It intends to restore the time-honored political tradition of the CCP and, at the same time, push reforms even further throughout China (Lam, 2015). This could be regarded as a traditionalist and reformist double-edged sword. Coincidently, both Trump and Xi seem to be pro-reform political leaders. These two presidents are both making hard efforts to reconnect with the alienated general public and foster decisive transformations in the fairly criticizable political ecology in their native country (Ross \& Bekkevold, 2016).

These two administrations are fully aware of the unsatisfied expectations from their own people and they are under the same pressure to deliver positive results of the changes initiated by them in the immediate future as convincing proof of the competence of their leadership. It is especially the case for Trump since the 2020 general election is literally approaching day by day. One thing is certain, both the US and China are in the motion of accelerated changes. New policies, new strategies, new institutions and so on are fast emerging to replace the previous ones. The global system has become visibly more volatile largely as a result of the intensifying power game between the US and China with the probability of increased frictions or even conflicts. A visually straight-forward summary of the similarities and differences between the Trump Administration and the Xi Administration is given in the table below (see Figure 1).

\section{Intensifying Power Struggles between the US and China: An Inevitable Collision?}

Based on direct and indirect observations, it seems that China is not under the 


\section{Similarities:}

Pro-Change or reform

Tough and strong leadership style

Conservatism and nationalism

\section{Differences:}

Unilateralism VS multilateralism

Pro-hegemony and confrontation VS pro-community with shared interests

Self-imposed isolationism VS inter-state cooperation and collaboration

Figure 1. The similarities and differences of the Trump Administration and the Xi Administration.

urgency to confront the US head-on and aggressively challenge its global domination at this point due to a number of constraining factors that occupy higher strategic priority than engaging in an all-out power struggle with the still much more powerful hegemon (Cohen, Greenberg, \& McGiffert, 2009). However, this doesn't mean confrontation has zero chance to break out between the US and China.

The relationship between the US and China is deteriorating largely due to the bitter "trade war" between these two largest economies on Earth. Signs indicate that President Trump is determined to play his signature "tough card" in the trade negotiations with China. The pressures from the US have steadily increased over the course of the on-going negotiations. According to Mr. Wang Shouwen (王受文), the vice commerce minister and deputy international trade representative of China, the US has been aggressively squeezing the margin of possible reconciliation for China and the US threatened to resort to the use of "extreme pressures" to force China to make even further concessions. He publicly denounced the insatiable greed and unacceptable aggressiveness of the US negotiation team by stating that "when you give them an inch, they want a yard (得寸进尺)”. It seems that China is reaching its limit of prudence and compromise. Even though China remains in a defensive position so far, the Chinese leadership is preparing for the worst if Donald Trump is determined to get his way.

The Chinese media stands firmly by the Xi Administration. Their unanimous voice is that the so-called "trade war" initiated by the Trump Administration is the Western containment against the rising China. Popular Chinese digital media even claims that the US has a malicious agenda to castrate the Chinese economy once and for all. The nationalist angle through which the current US-China trade war is portrayed by the Chinese media deserves strategic attention. China has always been a very proud nation-state (Jiang, 2017b). National pride and dignity have helped this enduring civilization to survive through extremely miserable atrocities in its modern and contemporary times (ibid.). Once the strong sentiment of nationalism and patriotism has been provoked among the Chinese general public, then the trade war would no longer be an economic matter, but a political matter with China's external sovereignty and dignity at 
stake. In short, China would not surrender to external coercive forces, especially when its people are unified by their collective identity and shared sense of pride.

It is noteworthy that both the Trump Administration and Xi Administration tend to resort to the ideological instrument of “conservative nationalism (保守 民族主义)” to consolidate their political support back home. This similarity shared by these two administrations is unlikely to contribute to mutual understanding and strategic cooperation between the US and China. On the contrary, it fuels the intensifying competitions and rivalries between these two mega forces. Mutually destructive power struggles tend to escalate across all the crucial dimensions since the strong desire to remain or become a powerful nation-state is more than evident on both sides. However, strategic self-restraint and policy prudency could help to stabilize the situation and prevent the outburst of an apocalyptic confrontation between these two powerful nation-states with catastrophic consequences to both of them as well as the rest of the world.

Fresh empirical evidences, including the second (although fruitless) summit between Trump and the current leader of North Korea-Kim Jong un (金正恩) in Hanoi, Vietnam and the finally settled trade deal (phase one) between the US and China, have indicated that China, again, has chosen compromise over confrontation for the sake of strategic prudence. However, China has been investing an enormous amount of efforts over the years to improve the competitiveness and resilience of its colossal economy (Yang \& Heng, 2018), encourage scientific advancement and technological innovation across all industrial sectors (Ding \& Li, 2015) and modernize the PLA step by step (Shambaugh, 2004). All these thoughtful endeavors and efforts of the Chinese political leadership would eventually pay off at a not-so-distant point of time in the future. By that time, I suppose compromise might no longer be an option for China to even consider.

\section{Stability of the Leadership: The Political Party and Power Succession}

Leadership is confined by time and power succession always poses uncertainty or even instability to any given political situation (Schedler, 2013). Also, the relationship between the president and his or her affiliated political party is also relevant and meaningful when it comes to truthfully evaluate the strength of the political leadership. To many of Trump's criticizers, Trump has abducted the entire Republican Party to support his one after another extraordinary political gambling. The establishment of the Republican Party also has warned that unconditional support to Trump would eventually take its toll back to the party as a whole and damage its image among the voters, especially the so-called "swing or floating voters". Whether or not Trump would be reelected in the 2020 general election remains to be anybody's guess. If the political legacy of Donald Trump is disruption and change, then his successor would have to decide whether or not to carry on the battles instigated by Trump or go into a very different direction. Inevitably, the infamous "Trump Era" would not last forever, especially if Donald Trump lost the general election in 2020. So far, the Republi- 
can Party doesn't seem to have a promising alternative candidate other than President Trump himself. Therefore, it's very likely that the Republican Party would still support Trump with solidarity just like it did in the 2016 general election, even though, internal criticism of and opposition to Trump remain fairly visible (Wilson, 2019).

In sharp contrast, Xi has successfully consolidated his power in the early years of his presidency. Now he firmly controls the power apparatus of the CCP together with a small number of other core members of the current leadership. Nevertheless, this doesn't mean $\mathrm{Xi}$ and his close allies do not face any internal resistance and challenge since the political struggles among the factions within the CCP are conceivably fierce (Lam, 2015). Even though they remain little known by outsiders, multifarious rumors and gossips about the internal political struggles within the party are circulating in the Chinese society as juicy entertainment rather than serious public affairs (ibid.). It has long been concluded by many insightful scholars both within and outside China that the private sphere and public sphere are not clearly separated in this country (Zheng, Lu, \& White, 2010).

Judging by Western democratic principles, the public sphere is dangerously weak in China, if not completely absent (ibid.). Chinese politics has very limited transparency and lacks direct participation from the general public due to political deliberations (ibid.). However, paradoxically, anything and everything in China is political and apolitical. The Chinese political regime doesn't just perform administrative function on behalf of the state. It is the state. In this sense, it's easy to distinguish Trump and his administration from the US as a sovereign entity and the American people. But it is very difficult to do the same thing in the case of China. The Chinese political leadership is intimately involved with literally everything going on within the national borders of China. The leadership style with Chinese characteristics is pervasive and saturated into every inch of the Chinese society, regardless critics appreciate it or not.

No matter how criticizable the party might seem to be, $\mathrm{Xi}$ is not intended to substantially reform the CCP at a speedy pace. Incremental changes are often preferred by the Chinese leadership as opposed to Trump-style sudden and dramatic changes (Zhao, 2013). For the Xi Administration, the best way to preserve the CCP is to impose ever strict internal discipline to the Chinese bureaucrats from top-down instead of subjecting the administrative power under the scrutiny of the rule of law and the Chinese general public. The high-profile “Chinese Dream (中国梦)” campaign led by the Xi Administration apparently reveals that Xi has other more prioritized strategic objectives and goals to accomplish during his (likely prolonged) tenure. He is absolutely determined to secure the monopolistic political status of the CCP in China as long as possible and restore the glory of China as a global superpower in the highly competitive international community. In other words, Xi wants to "make China great again", just like his American counterpart.

Xi's ambition reflects the collective aspiration of generations of ethnic Chinese 
worldwide. However, this ambition has been quickly captured by the US strategic radar. The "China Dream" together with the "made in China 2025" plan has been interpreted as China's official challenge to the US-centered global matrix of political economy (Appelbaum, 2018). Both sides are now planning strategic moves to secure their own objectives and goals and, simultaneously, prevent the opponent from achieving whatever it aims at. The high-profile "trade war" is only one episode of the political drama between the US and China. Many more might proceed over time.

\section{The Imperialistic America and a China-Centered New Global Order?}

Building a mighty empire across extensive territories seems to be the ultimate dream of powerful nation-states throughout the human history. Both the US and China are frequently condemned as imperialistic powers by the multitude of critics (Metcalf, 2012; Wallenfeldt, 2013; Frymer, 2017). The classic imperialism is characterized by the expansion of territory of the imperialist power and this type of territorial expansion is often driven by brutal military invasion to and occupation of the colonized countries, such as in the cases of the European colonial powers in the $18^{\text {th }}$ and $19^{\text {th }}$ centuries (Thomas, 2010; Joseph, 2017).

In comparative terms, the US as well as China does not have a heavy colonial heritage as the European major powers do, notably Britain and Spain. Nevertheless, many authors have insightfully pointed out that the US represents a distinctive form of imperialistic power that is significantly differentiated from the European colonial powers. The hegemon has achieved an unprecedented domination in literally all parts of the world after the historical victory of the Allies in WWII and the demise of the Communist Soviet Union in the early 90s. The so-called "unipolar world (单极世界)" dominated by the US has become a full-fledged existence almost immediately after. Even though the territorial boundaries of the US remain roughly constant over the decades (Burns, 2017), many argue that territorial expansion is definitely not the only defining feature of Imperialism (ibid.). The so-called "American Empire", in fact, takes a much more subtle form and, one should bear in mind that, it, fundamentally, contradicts with the US constitution, which is the ultimate source of legitimacy in the US (Statham, 2002; Burns, 2017).

It's widely known that the US has numerous military bases in literally all the strategically important localities on the planet for all the controversial reasons (Vine \& Winchester, 2015) and the aggressive presence of powerful US-based multinational corporations and financial institutions could be easily found in each and every major market there is (Gilpin \& Gilpin, 2006). In addition, the US has literally dominated all the well-established international organizations and institutions, from the International Monetary Fund (the IMF: 国际货币基 金组织) to the NATO with the incomparable capacity to enforce rules upon other states in order to advance its national interests in localities throughout the world (Skidmore, 2011). 
These are among the indisputable evidences of a peculiar form of global imperialism created and sustained by the hegemon itself. Achieving global domination with economized use of coercive force and strategic resources yet harvesting tremendous benefits at the same time are exceptionally tempting to all the major powers out there (Little \& Smith, 2006). It's fair enough to say, governing a unipolar global system with cost-effectiveness marks a new era of imperialism (ibid.). The US, in many ways, was and probably still is a very "smart power" (Joseph Nye) with skillful combination of equally impressive hard and soft powers and it spares no effort to preserve the existing global system in order to secure its globally extended national interests (Nye \& Olivieri, 2012). Having been on the sweetest spot for decades, it's understandable that any substantial challenge to the hegemonic status of the US would almost guarantee subsequent containment and retaliation in all the possible forms.

China is clearly aware of the immense beauty of this seemingly quite justifiable approach to dominate the world (Enright \& Hoffmann, 2008), even though, the country tends to go a great length to obscure its real strategic agenda from time to time. Many would agree that becoming a true global superpower requires ambition, time and appropriate strategies. China has been on the right track since the reforms led by Deng Xiaoping (邓小平) in the late 70s (Shambaugh, 2016). The future outlook of China depends crucially on the continuous success of the ongoing reforms within the country (ibid.). China's miraculous success does defy some of the enshrined principles according to the mainstream Western experiences (Leng \& Wu, 2014), such as mixing market mechanisms with heavy state interventions (Zheng \& Huang, 2018), de facto tolerance to administrative corruption (Kubbe \& Engelbert, 2018) and weak rule of law (Tsai, 2007) etc. The particularities of the heatedly debated "China Model" are in fact an integrated part of the intriguing Chinese exceptionalism rather than criticizable deviations from the standardized and universalized Western model of governance and development because contextual variations do make transplantation of successful foreign experiences into an indigenous environment much less effective than many would assume.

Nevertheless, despite the tremendous achievements so far, the vulnerabilities and uncertainties associated with the China Model have become increasingly evident (Ikenberry, Mastanduno, \& Wohlforth, 2011). Chinese labor used to be incredibly cheap and well-disciplined, which is one of the most explainable reasons why China has continuously attracted massive foreign investment since the economic opening-up in the late 1970s (Chow, 2015). But now, Chinese labor has become significantly more expensive and more aware of their legitimate rights and interests (ibid.). In other words, China is losing one of its major competitiveness in terms of low labor cost. At the current stage, climbing the global economic ladder seems to be the only viable option for the much anticipated "upgrading" of the Chinese economy (Jeffries, 2011). The ambitious "Made in China 2025" plan strongly suggests this strategic avenue China has been embarking on over the recent years, notably after its eventual accession in- 
to the World Trade Organization (the WTO: 世界贸易组织) in 2001.

Some economists believe this is a decisive qualitative transformation of the Chinese economy from lower-end complementarities to higher-end competitions (Lau, 2019). However, whether or not the Chinese political leadership could successfully cope with the pressing challenges in its economic domain remains to be an open question. If the Japanese economy could have remained in an afflicting stagnation for the past three decades after a golden period of high economic growth, similar situation could happen to China too, even though, the contributory causes may be significantly different (Auslin, 2017). It's not a secret that the Chinese economy is landing and some believe it to be a hard landing, if not crash landing (Biswas, 2016).

The momentum of China's booming economic growth is gradually slowing down over time. The US still seems to be highly alert towards the continuous rise of China on the other side of the planet. The Trump Administration does not even bother to conceal its strategic intention to aggressively contain the rising China through a full range of unusually tough measures. At this critical point, China remains to be prudent yet vigilant because 1) the country is still not powerful enough to fundamentally challenge the dominant status of the panWestern camp led by the US and 2) the domestic imperatives for political stability and socio-economic progressions are constantly strong (Economy, 2018), which increase the weight of potential opportunity costs as the result of unnecessary provocations to external retaliatory entities and forces.

Strategic profiling of China shows that social stability (Pan, 2012) and internal demand for better economic security and wellbeing (China Development Research Foundation, 2015; Wang, 2018) are treated with higher strategic priority by the Chinese political leadership than engaging in mutually destructive power struggles with the hegemon. The Chinese political leadership is expected to make sensible decisions in response to the internal imperatives and external influences and invest the precious resources selectively and wisely according to the order of priorities. It's noteworthy that both the Trump Administration and Xi Administration are under the heavy pressure from their own people to focus more inwardly rather than outwardly at this point (Freeman, 2012). For many members of the general public in the American and Chinese societies, if the strategic resources are limited and precious, then they should be utilized to benefit domestic citizens and local societies first (Hook \& Scott, 2012). Conceivably, the general public would be very disappointed and dissatisfied if they realized that foreign missions and affairs have siphoned a significant chunk of the scarce resources away from them.

The US has stuck in a self-created swamp of a series of military and non-military crusade in the Middle East in the names of anti-terrorism and democratization with astronomical expenditure and considerable reputational loss (Anderson \& Stanfield, 2018). The US has lost the moral high ground it used to occupy, i.e. as the leader of the Allies, largely due to unauthorized military interventions in for- 
eign soils, notably the invasion of Iraq and supporting the anti-government forces in the Syrian civil wars. The infamous “Arab Spring” (阿拉伯之春) instigated by the US-led Western coalition has seriously destabilized the entire Middle Eastern region and caused enduring turmoil in local societies (Brennan, 2016). Many blame the chaotic situation in the Middle East to the abuse of military power by the hegemon and its lack of moral considerations and strategic sensibilities. Now the hegemon wants to free itself from the seemingly never-ending obligations in post-intervention state-rebuilding and invest more resources to domestic priorities in order to settle the growing internal frustration over the unsatisfactory economic performance and well-being on both the macroscopic and microscopic levels, especially during and in the following years after the global financial meltdown in 2008 and 2009 (Maswood, 1990; Zuberi, 2009; Spitzer et al., 2013).

The Trump Administration is under a significant amount of pressure from the American people with a wide range of rather concrete and urgent demands, such as more secure and better-paid jobs (Zuberi, 2009), debt-free education (McPherson \& Schapiro, 1991) and affordable medical care (Niles, 2018) and so forth. Dysfunctional or defective social security system and economic precarity do upset many members of the general public in almost any given society. The competing demands for the scarce resources available could significantly constrain the political discretion of the political leadership. Even though, Trump has a strong strategic determination to force China out of the competition for the most prominent status in the international community. Eventually, he needs to gain the approval and support from the American general public in order to do so.

A two-front trade war against Mexico and China at the same time by the Trump Administration have already significantly hit the US equity market in early May of 2019 and the forecast of the annual economic growth is conservatively estimated to be around $2.5 \%$, despite a higher growth rate of $3.1 \%$ in the first quarter of 2019. Many forecasts predict that a significant slowdown of economic growth for the US in 2020 is very likely to happen due to the potential retaliatory measures from China and elsewhere. Since there is a significant "time lag" for potential gains of the trade war to take shape according to mainstream political-economic observers, President Trump might have to face a hard time in the 2020 general election because the economic statistics will not likely be on his side. If the key economic indicators did deteriorate considerably from early 2019 to 2020, then it would be conceivably difficult for Trump and his administration to convince the American voters that the trade war, among other political-economic adventures, is for the best interests of the US.

Even though China has never wanted to be targeted by the US, the country is simply too powerful and capable to avoid the containment. In the early 2000s, popular belief boldly claimed that the $21^{\text {st }}$ Century belongs to the rising China (Griffiths et al., 2011). Would China continue to rise and replace the US to be- 
come the next hegemon by the mid of the 21 st century is, at best, a premature speculation. What has been insightfully observed by a large number of scholars from various backgrounds is the quite apparent trend that the world is actually undergoing a process of proliferation and fragmentation (Zhang, 2010; Cordesman, 2014; Zhao, 2016). In other words, the unipolar system is deteriorating or even dissolving over time (ibid.). However, what the post-unipolar world would look like is yet to be known clearly. I personally speculate that a multipolar world order will develop even further in the near future. However, whether or not multi-polarization is just a transitioning period towards the re-concentration of power into a bipolar or another unipolar world order would remain to be anybody's guess, including well-informed and educated guesses.

The US and China do have many striking or even irreconcilable differences. However, these two mega forces share similar strategic pressure from domestic power dynamics and they are both constrained by the scarce strategic resources at their disposal. Despite various shared concerns and problems, the national behaviors of the US and China also at times align and at other times differ, which is largely contributed by their different ideologies, strategic visions and calculations and, needless to say, leadership styles. What deserves continuous intellectual attention is the strategic agenda that both the US and China want to weave a self-beneficial web of interrelated interests across all sorts of artificial boundaries to their own advantage and have a larger chunk of the pie as a result of that.

For those who believe the US and China have already collided, the power struggles between the two are both fierce and dangerous. Neither the US nor China would back down without a fight since the perceived interests at stake are extremely high. Unlike the Cold War, during which the amount of nuclear weapons of mass destruction have grown exponentially in between the US and the USSR, China has a very different political philosophy as well as an extensive repertoire of techniques and instruments to deal with the US. More importantly, it also has a long-standing political tradition to skillfully mediate, coordinate and network among the multitude of state and non-state political-economic agents and entities in order to effectively achieve whatever intended strategic objectives and goals in real-life situations. This distinctive feature of political practice makes China a more flexible and adaptive player in comparison with the hegemon. The often criticized Chinese pragmatism turns out to be a unique strength of the country in real-life political game, especially in non-Western or even anti-Western contexts.

\section{Interdependency and China's Expanding Influences in Foreign Territories}

China's spreading influences across the globe have built the foundation of its global leadership according to certain political observers. In this case, interdependency and China's pragmatic methods of foreign relation-building always 
deserve close attention. Interdependency is a well-established and very popular concept. To the institutionalists, it is the defining feature of the extremely complex webs of interrelated interests among numerous political-economic agents and entities across all levels (Keohane \& Nye, 2012; Jones, 2013). It's true that almost no state could stay self-contained in the Age of (on-going) Globalization, not even the most powerful ones, such as the US, or the most isolated ones, such as North Korea. In reality, many states rely upon critical foreign supply of energy and other strategically important resources, such as oil, gas and minerals, and many of the so-called global issues definitely require cooperation and collaboration of the nation-states, such as fighting against transnational terrorism, coping with environmental degradation and recovering from massive financial and/or economic crisis etc. Therefore, building supportive and productive relations with foreign states is crucial to China's implicit ambition to become a global superpower.

Institutionalists recognize the fact that interdependency is prone to be asymmetrical in reality and the so-called "asymmetrical dependency (不对称依赖)" is a critical source of power and influence for larger and more powerful nationstates (Fong, 2019). In terms of military capacity and presence per geographic area, China is obviously dwarfed by the US. However, China's economic ties with the rest of the world have grown exponentially in the past three decades. According to a fresh trade report released by the Center for Strategic and International Studies (the CSIS) based in Washington DC, China has already surpassed the US to become the world top trader. The report straightforwardly stated that "By 2017, China's total trade in goods had jumped to \$4.1 trillion or 12.4 percent of global trade. The US is the world's second largest trader at 11.9 percent of total trade, followed by Germany at 7.9 percent." It also reminded the audiences that "In 1995, the value of China's imports and exports of goods totaled $\$ 280.9$ billion or 3 percent of global trade". China literally has migrated from the periphery of the global economy to its center within merely twenty-some years. To some hawkish US-based strategists, today's China is simply a major player that the US can't live with or without. China has already built up extensive and intimate economic ties with many foreign states across the continents through trade relationships. A China-centered global economic web has been taking an increasingly evident shape (ibid.).

Higher degree of interdependency increases the potential losses of artificial economic disentanglement as the Trump Administration has been trying to do to "correct" the persistent US-China trade imbalance. It would be naive to assume that these interconnected and overlapping interests would prevent inter-state conflict from happening at all. However, it does significantly complicate the so-called "global power game" in many ways and it has also largely reduced the possibility of an all-out showdown between powerful states. Meanwhile, non-military forms of power struggles, including trade and currency warfare, cyber intrusion, technological embargo and political and economic exclusion or 
even sanction, just to name a few here, would stay intimately with global power politics as long as it exists.

President Trump's aggressive trade war against China is a typical example of these alternative battlefields of power politics. According to historic statistics, it's noteworthy that China generally has rather balanced trade relationships with most of its trading partners, except the US and Hong Kong (Keller \& Rawski, 2007). Even though the persistent trade deficit the US has with China over the years seems rather unsetting, a number of American economists and even politicians don't necessarily deem it as intentional and detrimental. They believe, other macroscopic factors, such as low saving rates of Americans, net inflow of capital and investment from outside of the country (United States International Trade Commission, 1998), high return potentials of the US domestic market and a recovering US economy could be the real attributes to this much misunderstood myth. Some economist have also pointed out that the increasingly complex value chain of globalized production and consumption fulfilled by cross-border economic agents and entities, especially the MNCs (Blanchard \& Shen, 2015), makes trade deficit or surplus a weaker indicator of economic wellbeing and it could be easily manipulated to serve the purpose of political provocation.

If the persistent US-China trade deficit could be demystified, even just partially, by sophisticated and critical understanding of the global political economy as whole, then one might easily doubt about the sensibility of Trump's trade crusade against China as well as others. A disqualified political leader like Donald Trump could lead the relatively declining hegemon to arbitrary and selfdestructive behaviors, even though his alleged intentions were to consolidate and defend national interests. Putting his inflated ego and ridiculous arrogance aside, Trump seems to have very limited understanding of the current global political economy. He relies heavily on "conventional wisdom" and his intuition rather than systematic logical reasoning and sophisticated understanding of how political economy actually works in reality. On top of that, Trump just does not take advice from professional political strategists due to trust issues. He mainly receives advice from his like-minded associates, including family members.

The arbitrary and provocative leadership style of the Trump Administration makes its Chinese counterpart look more coherent and sensible in comparison. China has always been an enthusiastic promoter of a multilateral, cooperative and mutually beneficial approach to deal with foreign relationships, even though, for sophisticated political observers, this approach is not immune from self-interested strategic calculations and political agendas. China insists on its "non-intervention" and "non-discriminatory" diplomatic principles, which, according to official Chinese diplomatic rhetoric, reflects China's great respect to other sovereign states regardless of their varied territorial sizes and national capacities (Harris, 2014).

In sharp contrast, Western powers openly and deliberately utilize a wide range of political-economic instruments to popularize their ideologies and model of 
governance and development in the so-to-speak "non-Western world". However, superficial emulations of successful Western experiences do not automatically guarantee success in non-Western societies as numerous empirical studies have meticulously documented many of the failed Westernization cases in all parts of the world (Badie, 2000; Mehmet, 2002).

In addition to that, the mandatory conditionality attached to foreign aid from the West, such as ensuring political accountability and clean governance, could significantly hurt the privilege and vested interest of the local political and economic elites (Stokke, 2013). Their resistance to the externally induced reforms is conceivably strong. In this case, China definitely offers an alternative collaborative opportunity since the country repeatedly claims that it would neither interfere with the "domestic affairs" nor intend to induce institutional transformations in other sovereign states. Obviously, this offer is exceptionally tempting and persuasive to the local political and economic elites. They could secure their privilege and vested interest in their native countries and, at the same time, receiving foreign assistance to boost local development in whatever desirable forms to further consolidate their own benefits.

In many ways, China is a competing force to the West. China's unique political pragmatism and model of governance and development have attracted enthusiastic supporters in many parts of the world, especially across the Global South where attempted Westernization has disillusioned the local societies for many complex and complicated reasons (Badie, 2000; Mehmet, 2002). China's seemingly non-intervention and value-neutral diplomatic principle are often accused by the West as “moral nihilism (道德虚无主义)" (Robinson \& Shambaugh, 2006). However, China is literally the "game-changing factor" in a deteriorating West-dominated global system. This rising superpower openly rejects some of the widely appreciated Western values and principles on a selective basis and tries to exert influences in places where the West does not necessarily have overwhelming competitive advantage. China is setting new standards and norms both at home and abroad. The Chinese political pragmatism intelligently circumvents undesirable moral and even legal restrictions of virtually all kinds ( $\mathrm{Yu}$, 1993). This intriguing political approach focuses solely on the outcome and it is highly dependent on the circumstances. In other words, it is goal-oriented and interest-based rather than being directed by ideological idealism and moral principles (Sutter, 2013). China's pragmatic foreign relation-building is highly fluid and adaptive with a surprising penetrating capacity to the rest of the world (ibid.).

In summary, interdependency could reduce the likelihood of arbitrary and abusive behaviors committed by states in extreme forms. It does not necessarily guarantee a more orderly and peaceful world where great powers still constantly compete and rival with one another. The logic of the game determines the outcome of the game. Interdependency is an inseparable constituent of the logic. It goes against President Trump's wishful intention to (at least, economically) disentangle with China through drastic and, likely, ineffective measures. The world 
as we know it has been becoming more and more interconnected over time. The complexity of global political economy has been increasing at the same time. It's almost impossible for any individual or administration to willfully reverse this trend. The backlash to the "self-imposed isolationism (自我孤立主义)" is likely to erupt if the Trump Administration goes too far. In this scenario, the US is voluntarily alienating its allies and alignments and creating more power vacuums for China, amongst others, to fill if it intends to.

\section{Conclusion}

In conclusion, leadership is critical to almost any collective existence in our world, from corporations to nation-states. To hard-core Realists, the so-called global leadership could be a euphemistic alternative for global domination in reality, even though, technically, they are not equivalents to each other that we could refer to interchangeably when examining international politics and political economy. Nevertheless, in order to truly understand the evolving "world order (世界格局)", which is characterized by its perceivable structural quality yet constantly being constructed and re-constructed, we need to bear in mind the well-established and time-honored Realist proposition that politics always revolves around interests regardless of their multifarious manifestations. Power struggles over self-defined national interests among powerful states or alliances of states largely determine the future outlook of the world we inhabit today and, inevitably, these struggles would last as long as human existence.

The world is not simply an arena of inter-state competitions and rivalries. Cooperation and collaboration are also crucial and needed, even though, one could argue that they are, in many cases, expedient rather than sincere. Various signs indicate that the unipolar world is gradually dissolving over time along with the (potentially) irreversible decline of the hegemon. It's increasingly hard for the US to sustain a unipolar global system alone since its national capacities have already been over-stretched and its competitive advantages have been diminishing in the recent decades, especially in terms of scientific advancement and technological innovation (Galama \& Hosek, 2008). China, among others, is catching up closer and closer. In the post-unipolar world, China, as long as it could maintain or even enhance its national capacities, should be one of the multiple poles out there, no matter how controversial the nature of the Chinese political regime is and how criticizable the behaviors of China are in the eyes of its opponents.

The world has been undergoing a process of transformation into a higher level of decentralization and fragmentation, for better or for worse. Some forces are driving states to bond them together in order to leverage the power of scale and collectivity, and, simultaneously, other forces are driving them apart. Traditionally, natural resources and territories are the key incentives of inter-state conflicts. However, as time goes by, controlling over strategically important global infrastructures has become one of the top priorities for the great powers nowadays. Some of these infrastructures are quite intangible and abstract, such as the 
financial infrastructure channeling the flows of capitals and investments across the globe or the digital understructure managing the movement of data and information. In other words, today's power politics is far more complex and complicated that it was centuries before. The bloody battlefields have extended far beyond the physical national borders into the expanding spheres of, for example, financial operation, global trade and cyber security.

The direct consequence of this is: no single state alone, no matter how powerful and influential it might be, has the capacity to resist or defy the operational logic of the system, especially considering the fact that globalization has been running deeper over time whether people appreciate it or not. Therefore, I suppose that the operational logic and mechanism of the global system are likely to outweigh the discretions of individual nation-states in the majority of the circumstances. A state-centered view is indeed insufficient and, sometimes, even counterproductive to examine global politics and political economy in today's conditions.

China is a rising superpower characterized by its idiosyncratic and indispensable "Chinese characteristics". The Chinese political authority maintains a unique leadership style and strategic thinking. The Xi Administration is apparently inspired by the indigenous Chinese political wisdom and philosophy. The vigor, flexibility and resilience of the Chinese political regime are the competitive strengths that deserve to be fully recognized and seriously considered by all stakeholders across the board. It is still unknown whether or not China would lead the world to an alternative future. However, one thing to be sure is, China is a game-changing factor to the status quo and this proud nation-state believes that it would unify the world in solidarity towards a shared future of all mankind.

\section{Limitations}

This article is not immune from limitations. Since the scope is prioritized over the depth, arguments could not go into much detail. Further elaborations on the arguments in more depth are definitely needed and beneficial. The generalizability of the conclusions is rather limited due to the fact that they are very country-specific and time-sensitive. Longitudinal researches over the on-going political game between the US and China could be very valuable and they are strongly encouraged in order to yield more insights regarding today's global power politics and political economy.

\section{Conflicts of Interest}

The author declares no conflicts of interest regarding the publication of this paper.

\section{References}

Acharya, A. (2018). The End of American World Order (2nd ed.). Cambridge, UK: Polity Press. 
Anderson, L., \& Stanfield, G. (2018). The Future of Iraq: Dictatorship, Democracy or Division? New York: Macmillan.

Appelbaum, R. (2018). Innovation in China: Challenging the Global Science and Technology System. Cambridge: Polity Press.

Auslin, M. (2017). The End of the Asian Century: War, Stagnation, and the Risks to the World's Most Dynamic Region. London: Yale University Press.

Badie, B. (2000). The Imported State: The Westernization of the Political Order. Stanford, CA: Stanford University Press.

Baldwin, D. (2008). Theories of International Relations. London: Routledge.

Bergeijk, P., Okano-Heijmans, M., \& Melissen, J. (2011). Economic Diplomacy: Economic and Political Perspectives. Leiden: Martinus Nijhoff Publisher.

Biswas, R. (2016). Future Asia: The New Gold Rush in the East. London: Palgrave.

Blanchard, J., \& Shen, S. (2015). Conflict and Cooperation in Sino-US Relations: Change and Continuity, Causes and Cures. London: Routledge. https://doi.org/10.4324/9781315767710

Bonn, S. (2010). Mass Deception: Moral Panic and the U.S. War on Iraq. New Brunswick, NJ: Rutgers University Press.

Brennan, C. (2016). Fall of the Arab Spring: From Revolution to Destruction. San Diego, CA: Progressive Press.

Burns, A. (2017). American Imperialism: The Territorial Expansion of the United States, 1783-2013. Edinburgh: Edinburgh University Press.

Busch, T. (2014). Value-Based Leadership in Public Professions. New York: Palgrave Macmillan.

China Development Research Foundation (2015). Chinese Economists on Economic Reform. London: Routledge.

Chow, G. (2015). China’s Economic Transformation (3rd ed.). Oxford: Wiley Blackwell.

Cohen, W., Greenberg, M., \& McGiffert, C. (2009). Smart Power in U.S.-China Relations: A Report of the CSIS Commission on China. Washington DC: Center for Strategic and International Studies.

Coleman, S. (2017). Organizational Change Explained: Case Studies on Transformational Change in Organizations (1st ed.). London: Kogan Page.

Cordesman, A. (2014). Chinese Strategy and Military Power in 2014: Chinese, Japanese, Korean, Taiwanese and US Perspectives. Washington DC: The Center for Strategic and International Studies.

Dickson, B. (2016). The Dictator's Dilemma: The Chinese Communist Party's Strategy for Survival. Oxford: Oxford University Press.

Ding, X., \& Li, J. (2015). Incentives for Innovation in China: Building an Innovative Economy. New York: Routledge. https://doi.org/10.4324/9781315726717

Doob, C. (2017). Social Inequality and Social Stratification in U.S. Society. New York: Routledge.

Dyer, J. (2019). The Façade of Excellence Defining a New Normal of Leadership. Milton: Productivity Press.

Economy, E. (2018). The Third Revolution: Xi Jinping and the New Chinese State. Oxford: Oxford University Press.

Edmondson, A. (2013). Teaming How Organizations Learn, Innovate, and Compete in the Knowledge Economy. San Francisco, CA: Jossey-Bass. 
Enright, M., \& Hoffmann, J. (2008). China into the Future: Making Sense of the World's Most Dynamic Economy. Singapore: Wiley.

Fitzduff, M. (2017). Why Irrational Politics Appeals: Understanding the Allure of Trump. Santa Barbara, CA: ABC-CLIO, LLC.

Fong, G. (2019). Export Dependence versus the New Protectionism: Constraints on Trade Policy in the Industrial World. London: Routledge.

Freeman, J. (2012). American Empire: The Rise of a Global Power, the Democratic Revolution at Home. New York: Viking.

Frymer, P. (2017). Building an American Empire: The Era of Territorial and Political EXpansion. Princeton, NJ: Princeton University Press.

Galama, T., \& Hosek, J. (2008). U.S. Competitiveness in Science and Technology. Santa Monica, CA: RAND Corp.

Garver, J. (2018). China's Quest: The History of the Foreign Relations of the People's Republic of China. Oxford: Oxford University Press.

Gilpin, R., \& Gilpin, J. (2006). The Challenge of Global Capitalism: The World Economy in the 21st Century. New Delhi: New Age International (P) Limited, Publishers.

Green, D. (2015). Constructivism and Comparative Politics. Abingdon: Routledge. https://doi.org/10.4324/9781315291093

Griffiths, R., Kissinger, H., Zakaria, F., Ferguson, N., \& Li, D. (2011). Does the 21st Century Belong to China? Toronto: Anansi.

Harris, S. (2014). China's Foreign Policy. Cambridge: Polity.

Hook, S., \& Scott, J. (2012). U.S. Foreign Policy Today: American Renewal? Washington DC: CQ Press.

Ighodaro, E. (2017). Game Changer: Winning Political Victories without Compromise. Pittsburgh: ROSE DOG Books.

Ikenberry, G., Mastanduno, M., \& Wohlforth, W. (2011). International Relations Theory and the Consequences of Unipolarity. Cambridge: Cambridge University Press. https://doi.org/10.1017/CBO9780511996337

Jeffries, I. (2011). Economic Developments in Contemporary China. London: Routledge. https://doi.org/10.4324/9780203834626

Jiang, G. (2017a). Corruption Control in Post-Reform China: A Social Censure Perspective. Singapore: Springer.

Jiang, S. (2017b). China's Hong Kong: A Political and Cultural Perspective. Singapore: Springer.

Jones, R. (2013). Globalisation and Interdependence in the International Political Economy: Rhetoric and Reality. New York: Bloomsbury.

Joseph, P. (2017). The SAGE Encyclopedia of War: Social Science Perspectives. Los Angeles, CA: SAGE Reference. https://doi.org/10.4135/9781483359878

Karadağ, E. (2015). Leadership and Organizational Outcomes Meta-Analysis of Empirical Studies. Cham: Springer International Publishing.

Karatnycky, A., \& Piano, A. (2018). Freedom in the World: The Annual Survey of Political Rights and Civil Liberties. London: Routledge, Taylor \& Francis Group.

Keller, W., \& Rawski, T. (2007). China's Rise and the Balance of Influence in Asia. Pittsburgh, PA: University of Pittsburgh Press.

Keohane, R., \& Nye, J. (2012). Power and Interdependence. Boston, MA: Longman.

Kubbe, I., \& Engelbert, A. (2018). Corruption and Norms: Why Informal Rules Matter. 
New York: Palgrave Macmillan. https://doi.org/10.1007/978-3-319-66254-1

Lagunes, P., \& Rose-Ackerman, S. (2015). Greed, Corruption, and the Modern State: Essays in Political Economy. Northampton, MA: Edward Elgar. https://doi.org/10.4337/9781784714703

Lam, W. (2015). Chinese Politics in the Era of Xi Jinping: Renaissance, Reform, or Retrogression? New York: Taylor and Francis. https://doi.org/10.4324/9781315719368

Lau, L. (2019). The China-US Trade War and Future Economic Relations. Hong Kong: The Chinese University Press. https://doi.org/10.1142/S2591729319500123

Leng, T., \& Wu, Y. (2014). Chinese Models of Development: Global, Local, and Comparative Perspectives. Lanham, MD: Lexington Books.

Leverett, F., \& Indyk, M. (2005). The Road Ahead: Middle East Policy in the Bush Administration's Second Term. Washington DC: Brookings Institution.

Little, R., \& Smith, M. (2006). Perspectives on World Politics. London: Routledge.

Martin, P. (2018). 5 Steps to a 5 AP World History 2018 Edition. New York: McGraw-Hill Professional Publishing.

Maswood, SJ (1990). Japanese Defense: The Search for Political Power. Singapore: Institute of Southeast Asian Studies.

McPherson, M., \& Schapiro, M. (1991). Keeping College Affordable: Government and Educational Opportunity. Washington DC: The Brookings Institution.

Medeiros, E. (2009). China's International Behavior. Activism, Opportunism, and Diversification. Fort Belvoir: Defense Technical Information Center.

Mehmet, O. (2002). Westernizing the Third World: The Eurocentricity of Economic Development Theories. London: Routledge. https://doi.org/10.4324/9780203055519

Mercer, I. (2016). The Trump Revolution: The Donald's Creative Destruction Deconstructed. Issaquah, Washington DC: Politically Incorrect Press.

Metcalf, M. (2012). Imperialism with Chinese Characteristics?: Reading and Re-Reading China's 2006 Defense White Paper. Washington DC: United States Department of Defense.

Molchanov, M., Knight, W., \& Masciulli, J. (2016). The Ashgate Research Companion to Political Leadership. London: Taylor and Francis.

Monagan, S. (2016). Fascist Trump How Donald Trump's Rhetoric Is Jeopardizing US National Security. Raleigh, NC: Lulu Press.

Nau, H., \& Ollapally, D. (2013). Worldviews of Aspiring Powers: Domestic Foreign Policy Debates in China, India, Iran, Japan and Russia. Oxford: Oxford University Press.

Niles, N. (2018). Basics of the U.S. Healthcare System. Burlington, VT: Jones \& Bartlett Learning.

Nye, J. (2016). Is the American Century over? Cambridge, UK: Polity Press.

Nye, J., \& Olivieri, A. (2012). Smart Power. Roma: GLF Editori Laterza.

Oforchukwu, J. (2011). Perspectives on Leadership: A Synthesis of Types and Theories. Bloomington, IN: AuthorHouse.

Pan, Z. (2012). Conceptual Gaps in China-EU Relations: Global Governance, Human Rights and Strategic Partnership. Basingstoke: Palgrave Macmillan.

Podliska, B. (2010). Acting Alone: A Scientific Study of American Hegemony and Unilateral Use-of-Force Decision-Making. Lanham, MD: Lexington Books.

Qian, Z. (2018). The Road to Socialism with Chinese Characteristics. Reading: Paths International Limited. 
Rackaway, C. (2017). Civic Failure and Its Threat to Democracy. New York: Lexington Books.

Robinson, T., \& Shambaugh, D. (2006). Chinese Foreign Policy: Theory and Practice. Oxford: Clarendon.

Ross, R., \& Bekkevold, J. (2016). China in the Era of Xi Jinping: Domestic and Foreign Policy Challenges. Washington DC: Georgetown University Press.

Rost, J. (2008). Leadership for the Twenty-First Century. Enskede: TPB.

Saunders, F. (2013). The Cultural Cold War: The CIA and the World of Arts and Letters. New York: The New Press.

Schedler, A. (2013). The Politics of Uncertainty: Sustaining and Subverting Electoral Authoritarianism. Oxford: Oxford University Press.

Schmidt, S., Shelley, M., \& Bardes, B. (2018). American Government and Politics Today: Essentials 2017-2018 Edition. Boston, MA: Cengage Learning.

Shambaugh, D. (2004). Modernizing China's Military-Progress, Problems, and Prospects. Berkeley, CA: University of California Press.

Shambaugh, D. (2016). China's Future (1st ed.). Cambridge: Polity Press.

Skidmore, D. (2011). The Unilateralist Temptation in American Foreign Policy. New York: Routledge. https://doi.org/10.4324/9780203839720

Sobel, A. (2013). International Political Economy in context: Individual Choices, Global Effects. Los Angeles, CA: Sage.

Solomon, R., \& Quinney, N. (2010). American Negotiating Behavior: Wheeler-Dealers, Legal Eagles, Bullies, and Preachers. Washington DC: United States Institute of Peace.

Spitzer, C., Wiedemer, R., Janszen, E., \& Wiedemer, D. (2013). America's Bubble Economy: Profit When It Pops. Hoboken, NJ: Wiley.

Statham, E. (2002). Colonial Constitutionalism: The Tyranny of United States' Offshore Territorial Policy and Relations. Lanham, MD: Lexington.

Sterling-Folker, J. (2002). Theories of International Cooperation and the Primacy of Anarchy. Albany, NY: State University of New York Press.

Stokke, O. (2013). Aid and Political Conditionality. Hoboken, NJ: Taylor and Francis. https://doi.org/10.4324/9780203044094

Sutter, R. (2013). Foreign Relations of the PRC: The Legacies and Constraints of China's International Politics Since 1949. Lanham, MD: Rowman \& Littlefield.

Thomas, N. (2010). Missions and Unity: Lessons from History, 1792-2010. Eugene, OR: Cascade Books.

Torres, A., \& Sable, M. (2018). Trump and Political Philosophy: Leadership, Statesmanship, and Tyranny. Gewerbestrasse: Palgrave.

https://doi.org/10.1007/978-3-319-74445-2

Tsai, K. (2007). Capitalism without Democracy: The Private Sector in Contemporary China. London: Cornell University Press.

United States International Trade Commission (1998). Implications for U.S. Trade and Competitiveness of a Broad-Based Consumption Tax. Washington DC: U.S. International Trade Commission.

Vine, D., \& Winchester, S. (2015). Base Nation: How U.S. Military Bases Abroad Harm America and the World (1st ed.). New York: Metropolitan Books.

Wallenfeldt, J. (2013). U.S. Imperialism and Progressivism. New York: Britannica Educational Pub. in Association with Rosen Educational Services. 
Wang, L. (2018). China's WTO Accession Reassessed. London: Routledge.

Williams, D., \& Prince, K. (2018). The Monstrous Discourse in the Donald Trump Campaign. Lanham, MD: Lexington Books.

Wilson, R. (2019). Everything Trump Touches Dies: A Republican Strategist Gets Real about the Worst President Ever. New York: Simon \& Schuster.

Yang, M., \& Heng, M. (2018). Global Financial Crisis and Challenges for China. Singapore: World Scientific Publishing.

Yu, G. (1993). China in Transition: Economic, Political, and Social Developments. Lanham, MD: University Press of America.

Zhang, Y. (2010). Rising China and World Order. Hackensack, NJ: World Scientific. https://doi.org/10.1142/7710

Zhao, S. (2013). China's Search for Energy Security: Domestic Sources and International Implications. New York: Routledge.

Zhao, S. (2016). Chinese Foreign Policy: Pragmatism and Strategic Behavior: Pragmatism and Strategic Behaviors. London: Routledge. https://doi.org/10.4324/9781315705767

Zheng, Y., \& Huang, Y. (2018). Market in State: The Political Economy of Domination in China. Cambridge: Cambridge University Press. https://doi.org/10.1017/9781108562119

Zheng, Y., Lu, Y., \& White, L. (2010). Politics of Modern China: Political Economy. London: Routledge.

Zuberi, D. (2009). Differences That Matter: Social Policy and the Working Poor in the United States and Canada. London: Cornell University Press.

\section{Websites Consulted}

https://www.cnbc.com/2019/05/31/trumps-escalating-trade-war-gives-heat-to-p utin-and-xis-growing-bromance.html

https://www.cato.org/publications/congressional-testimony/causes-consequence s-us-trade-deficit

https://chinapower.csis.org/trade-partner/ 